\title{
NEW APPROACHES IN BIOLOGICAL WASTEWATER TREATMENT AIMED AT REMOVAL OF ORGANIC MATTER AND NUTRIENTS
}

\author{
NOWE PODEJŚCIA W DZIEDZINIE BIOLOGICZNEGO \\ OCZYSZCZANIA ŚCIEKÓW ORAZ USUWANIU MATERII ORGANICZNEJ \\ I SUBSTANCJI ODŻYWCZYCH
}

\begin{abstract}
The article presents the developed anaerobic-aerobic wastewater treatment technologies. These technologies aimed at removing the organic matter, nitrogen and phosphorus by means of microorganisms immobilized on fibrous carrier surfaces. The results of the laboratory research show the high efficiency of milk wastewater treatment. The following degrees of reduction were achieved for the pollutant indicators: COD 86.7-93\%, total nitrogen - 96.9-97.9\%. Compared to the traditional treatment technologies applied in Ukraine, these values are high. The concentration of organic matters and biomass of not attached bacteria decreased in bioreactor chambers. When the purification process ends, a small amount of excess biomass remains; therefore, its self-oxidation and self-regulation occurs as a result of consumption by the organisms occupying higher levels of trophic chains. The use of anaerobic-aerobic bioreactors system for the treatment of wastewater enables achieving high outflow quality and prevents the suspended substances from slipping. Immobilization of microorganisms on the first stage of the technology prevents the formation of big amount of excessive sludge and removes biomass from the bioreactor, which allows the technology even for the heavily polluted wastewater. In reactors containing immobilized microorganisms, the organic matter compounds used in subsequent reactors for phosphate accumulation are split. The presented biotechnology saves electric energy, provides sufficient quality of treatment, and ensure the compliance of treated wastewater with the effluent standards.
\end{abstract}

Keywords: wastewater, anaerobic-aerobic wastewater treatment, microorganism's immobilization, bioreactor, artificial fibrous carriers

\section{Introduction}

The pollution of surface water is mainly caused by the discharge of industrial and domestic wastewater that was treated insufficiently. Such situation results in decomposition of organic contaminants, anaerobic processes, algal bloom, overgrowth as well as prevents

\footnotetext{
${ }^{1}$ Department of Environmental Biotechnology and Bioenergy, Faculty of Biotechnology and Biotechnics, National Technical University of Ukraine "Igor Sikorsky Kyiv Polytechnic Institute", Yangel 3 build. 4, 03056 Kiev, Ukraine, phone +380442049779, email: larisasabliy@ukr.net

${ }^{2}$ Polish Academy of Sciences, Scientific Center in Kyiv, st. B. Khmelnitsky 49, k. 4, 01030 Kyı, Ukraine, phone/fax +380442340216

*Corresponding author: larisasabliy@ukr.net
} 
water bodies from being used for recreational purposes. The wastewater produced by different industries (automotive, chemical, food, etc.), is especially hazardous due to the high concentrations of heavy metal ions, suspended solids, detergents, fats, organic macromolecular compounds, helminth eggs etc.

Nutrients found in the water contribute to a rapid growth of algae in the reservoir and lead to the secondary water pollution, colority and temperature change, impoverishment of dissolved oxygen and, deterioration of organoleptic indicators of water. These factors not only complicate the use of the water in the water supply of residential areas and enterprises, but also affect natural processes taking place in reservoirs. Since water absorbs carbon dioxide from air, it is impossible to limit the concentration of this source of carbon in surface water bodies, and nitrogen compounds are able to gasify and disappear from the water medium during metabolic processes. Therefore, prevention of eutrophication by minimizing the content of phosphates in effluent seems rational [1]. With the development of food industry in Ukraine, namely factories of baked goods, confectionery, beer, the malt production, has significantly increased both for local and export markets. The content of phosphates in the effluent (of utility and food industry) over the last five years has changed from 9 to $40 \mathrm{mg} / \mathrm{dm}^{3}$, however, the treatment technology remains unchanged. As a result, eutrophication takes places in reservoirs.

When the effluent reaches a mechanical treatment unit, the problems of regular tankage exportation and tankage recycling emerge. Moreover, small parts of seeds and seedlings are not extracted completely, reaching the next plant devices. In biological part of treatment plants, malfunctions caused by toxic effects of high concentrations of effluent polluting substances can be observed. The traditional biological treatment in aeration tanks [1-3] still quite popular in Ukraine (aerobic oxidation process with activated sludge) is predominantly employed in the treatment of municipal and industrial wastewater (including, for instance, dairy wastewater). Utilizing such technology has a number of disadvantages: it impacts the effectiveness of treating wastewater, causes irregularity of revenue expenditure and concentrations of pollution. It is also dependent on the temperature (low temperature slows down the process) and $\mathrm{pH}$, toxic to activated sludge substances (surfactants, heavy metal ions, dyes, etc.), creates a discrepancy between the treated water quality and the established standards (mainly relating to phosphorus and nitrogen compounds). Moreover, a problem with sludge occurs due to the development of filamentous bacteria and as a result, poor separation of it from the treated water. A large amount of sludge requires significant investments in processing and utilization.

The analysis of physical and chemical content of samples polluted with industrial wastewater indicates a large concentration of organic substances dispersed in different states, small correlation between COD and BOD as well as easy biochemical oxidation of organic substances lead to biological purification by microorganisms biocenosis in different oxygen conditions, both for separate sewage of plants and combined purification with urban wastewater. Treatment of mentioned wastewater is conducted with the use of biological methods, for example, in aeration tanks, in high rate filters, in circulative oxidizing channels or in two step schemes with aeration tanks [1,2].

The disadvantages of traditional aerobic biological wastewater treatment technologies (aeration tank - secondary sedimentation tank) involve high electricity consumption by air supply in the aeration tanks, high rate filters, substantial growth of surplus activated sludge biomass which requires conducting the stabilization process and is hard to dewater. The seasonal and periodic operation of the industry contributes to the instability in the 
operation of aerobic tanks. The presence of organic matter in high concentrations may result in overload as well as activated sludge bulking or changing of flock structure, thus hindering the secondary sedimentation tanks operation $[1,3]$.

Scientific publications showed that the development of wastewater treatment technology involving removal of organic substances - especially from wastewater with significant shear of effluent from food industry, should be given priority and new technologies. In such a cases can be mentioned following technologies: anaerobic with granular activated sludge in UASB-reactors; anaerobic-aerobic; uniflow bioconveyer using immobilized microorganisms; nitro-denitrification and biological phosphate removal: Ludzak-Ettinger, Bardenpho, JHB, University of Cape Town (UCT-process), A/O, Phoredox; anammox-process should be considered [2, 4-9]. In the Johannesburg system, the mixed liquor originating from the aerobic zone flows past the settler, whereas the return sludge flows to the anoxic zone. In the UCT, there is no need to introduce nitrate in the anaerobic zone, since the recycle stream originates from the aerobic zone rather than from the anoxic one. In the latter, the nitrate concentration is maintained low, because the recirculation ensures that the available denitrification capacity is always greater than the amount of nitrate for denitrification. The modified UCT system was created to prevent nitrate introduction in the anaerobic zone, also in the case where the concentration of nitrate in the excess of the denitrification capacity is variable. The anoxic zone is divided into two parts; in the first part (upstream), the return sludge is introduced, whereas the second (downstream) part is used for denitrifying the recycled nitrate. Under such conditions, the denitrification in the anoxic zone is complete and no nitrate returns to the anaerobic zone. This configuration has a drawback, namely the anoxic zone is under-loaded with nitrate. Hence, it is necessary to provide greater total anoxic volume, in comparison to the modified Bardenpho system. If the anoxic volume is kept unchanged, the nitrate concentration will increase in the effluent, potentially causing problematic issues in the sedimentation tank (floating sludge), demanding additional method of sludge treatment or usage of membranes [10-16]. The A/O system is characterized by the same configuration as in the case of the Phoredox, Bardenpho system; however, the anaerobic zone is compartmentalized, inducing a plug-flow regime that improves the removal capacity of phosphorus as well as facilitates converting the easily biodegradable material to acetate [11-16]. While comparing the existing schemes of biological phosphate removal or recovery from wastewater presented in literature, it is necessary to distinguish their advantages and disadvantages. Phoredox scheme is used if removal of nitrogen is not necessary, since sludge must be with short age. Phoredox system is widespread in Europe and the parts of U.S. with a cold climate. In countries with temperate and warm climates, Phoredox is used to a limited degree, since nitrification is not complete even with short age of sludge. The nitrates in the anaerobic zone adversely affect the first stage of dephosphatation and reduce the effectiveness of removal [17-21].

All systems have a particular application and to achieve the best treatment effect, must have a sufficiently large volume of reactors bear the operating costs associated with a complex system of recycling and maintenance of pumps or proper decantation system in case of sequence batch reactors as well as system for measurement and control [21-25].

New approaches are implemented in recommended biotechnology of food industry wastewater treatment. Namely is microorganisms immobilized that create high levels of trophic chains; the use of fiber carriers with a large surface area; small amount of sludge is formed, which dewaters well; minimizing expenses for the recirculation wastewater. 


\section{Materials and methods}

The research of biological wastewater treatment was contained two parts. The aim of the first study is removing the organic matter and nitrogen compounds. The second part of study was focused in removing phosphorus.

The first part of study was performed on a pilot plant installation (see Fig. 1). It comprised two anaerobic, as well as two anoxic and aerobic bioreactors that were connected sequentially.

The assessment of COD in the effluent was carried out on the basis of standard procedure using dichromate method. The potentiometric method involving the use of ion selective electrodes was used to assess the nitrogen concentration found in the effluent.

Wastewater was supplied to the first anaerobic bioreactor and then passed through the following anaerobic and aerobic bioreactors.

The pumps located at the bottom of the anaerobic bioreactors as well as the perforated recirculation pipe with holes enabling to sprinkle water, were employed in order to carry out mixing of the reacting masses. The required quantity of air was provided to the anoxic chambers by means of a micro-compressor, in order to keep the concentrations of dissolved oxygen at the level of $0.1-0.2 \mathrm{mg} / \mathrm{dm}^{3}$ and in the case of the aerobic chamber - within $1.6-2.5 \mathrm{~g} / \mathrm{m}^{3}$.

The biomass immobilization was performed by installing the carriers made of VIYA (Eyelash) type artificial fibers [26] in the bioreactors. The specific surface carriers gradually reduced from approximately $3800-3700 \mathrm{~m}^{2} / \mathrm{m}^{3}$ in the anaerobic bioreactors to $380 \mathrm{~m}^{2} / \mathrm{m}^{3}$ in aerobic ones (ratio of carrier area expressed in $\mathrm{m}^{2}$ to the volume of medium reactor $\left.-\mathrm{m}^{3}\right)$.

Initially, the activated sludge obtained from Kyev-based "Bortnitskaya" WWTP was added to the bioreactors in order to accelerate increasing the biomass amount as well as add the $\mathrm{NaNO}_{3}$ and $\mathrm{K}_{2} \mathrm{HPO}_{4}$ solutions to wastewater.

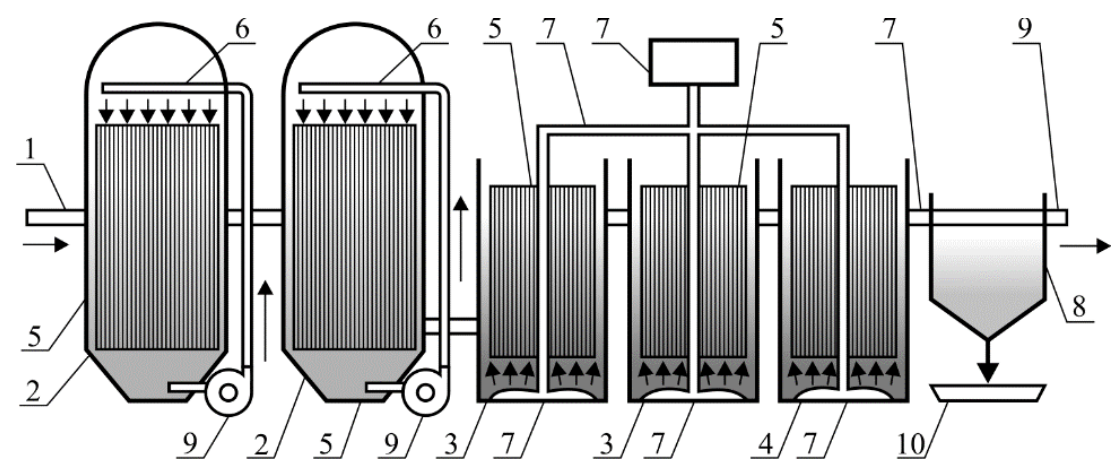

Fig. 1. Scheme of pilot plant installation: 1 - wastewater supply; 2 - anaerobic bioreactors (sect. No. 1 and sect. No. 2); 3 - anoxic bioreactors (sect. No. 3, sect. No. 4); 4 - aerobic bioreactor (sect. No. 5); 5 - fibers carriers installation; 6 - perforated pipe of recirculation wastewater; 7 - air supply system; 8 - secondary settling tank; 9 - treated water pipe; 10 - sludge squares

The second part of study presented in the paper involved the phosphates removal. The investigations were performed on an experimental operation-performing device employing the bioreactors with immobilized microorganisms as well as activated sludge. 
It was based on the biological treatment system with anaerobic-aerobic bioreactors. The general principles of applied technological line are similar to the ones shown in Figure 1.

The assessment of COD in the effluent was carried out on the basis of a standard procedure using dichromate method. The photocolorimetric method was used to assess the concentration of phosphates in the effluent, since orthophosphates - after reaction with molybdate in the sulfuric acid medium in the presence of trivalent antimony ions and after the recovery of ascorbic acid - turn blue, the intensity of which enables to assess the concentration of phosphates. Absorbance was measured on a spectrophotometer at $\lambda=670 \mathrm{~nm}$.

The effluent from malt factory was selected for the study. This type of industrial effluent is difficult to treat due to a great content of colorants, coarsely dispersed particles, and suspended substances, changing of spillover as well as polluting substances concentration. The content of COD reaches $1700-3500 \mathrm{mg} \mathrm{O} / \mathrm{dm}^{3}$, while the value of $\mathrm{PO}_{4}{ }^{3-}$ amounts to $14-60 \mathrm{mg} / \mathrm{dm}^{3}$ during experiment.

In this experimental WWTP, the influent is pumped from tray into the holding tank. The tank is equipped with a pipe and a valve for water flow control. The tank is elevated, whereas the bioreactors are recessed to ensure the gravitational wastewater flow. Moreover, the tank has an emergency overflow system, which is triggered when the level of water raises up to $10 \mathrm{~cm}$ from the top, through the excess water overflow received by the integrated line and returned back into the tray in order to prevent the sewage spillage (Fig. 2).

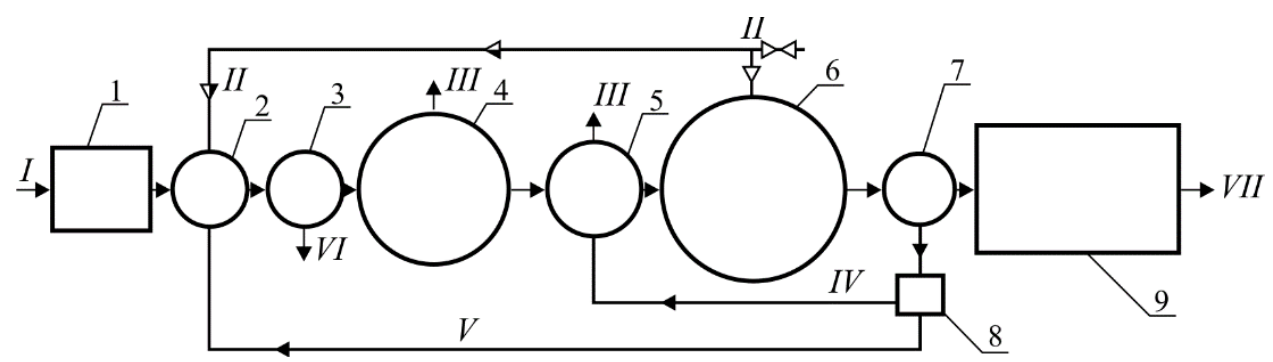

Fig. 2. The scheme showing the experimental installation involving biological malting wastewater treatment for the phosphates refining: 1 - mechanical treatment device; 2 - biocoagulator with aerobic condition; 3 - sedimentation tank; 4 - bioreactor with fibers carriers "eyelash" with anaerobic conditions; 5 - FAO bioreactor with anaerobic conditions; 6 - FAO bioreactor with aerobic conditions; 7 - sedimentation tank; 8 - pump; 9 - bioponds system; I - inlet of wastewater; II - air supply system; III - system for biogas allocation and storage; IV - activated sludge recirculation; V - sludge recirculation; VI - excess sludge (to the press filter); VII - purified wastewater

The wastewater from the storage tank is taken to biocoagulation in order to remove suspended solids and coarse particles. The volume of biocoagulation tank is $30 \mathrm{dm}^{3}$. A system of aeration is arranged within an aerobic bioreactor. The pipeline to the aerobic bioreactor is supplied with air from a compressor station and is regulated by a valve. The wastewater enters the settler, where the separation of the wastewater and sludge from an excess sludge occurs. The volume of the settler is $40 \mathrm{dm}^{3}$. The tankage is removed by piping sludge beds. Then, the water flows into a bioreactor with immobilized 
microorganisms to decompose organic material. In this stage the main reduction of the concentration of organic substances and their transformation into more accessible for phosphate accumulating organisms (PAOs) takes place. Bioreactor is equipped with a pipeline for gas removal. A pump with tubing and nozzles for mixed surface and carriers water irrigation provide mass transfer in the bioreactor. The pump with the lower water intake takes water up. Fastening pipes distribute water flow in different directions.

By conducting treatment in a bioreactor employing immobilized microorganisms it is possible to decrease the COD value to $500-800 \mathrm{mg} \mathrm{O}_{2} / \mathrm{dm}^{3}$.

After anaerobic bioreactor with immobilized microorganisms the water goes into another anaerobic bioreactor, equipped with the pump for stirring and maintaining the activated sludge or suspended substances. Subsequently, water enters an aerobic bioreactor. The air in the experimental plant comes from the common system of air supply to the treatment system of the malt plant. The system of perforated aeration pipes is arranged at the bottom of the reactor and consists of perforation pipe with a diameter of $13 \mathrm{~mm}$.

\section{Results and discussion}

After biofouling increased on the surface of carrier during performance of first part of study, dry matter biomass concentration reached $20-30 \mathrm{~g} / \mathrm{dm}^{3}$ within 45 days of the installation in the anaerobic bioreactor uniflow and decreased to $3.2 \mathrm{~g} / \mathrm{dm}^{3}$ within the aerobic bioreactor. Initially, high concentrations of contaminants such as ammonia nitrogen, nitrite, nitrate and COD were found in the treated wastewater, after twenty days of operation (flow mode).

The expected treated water quality was achieved following 45 days $\left[\mathrm{mg} / \mathrm{dm}^{3}\right]$ : the value of COD past the $2^{\text {nd }}$ stage in the anaerobic bioreactor amounted to 300 ; in turn, COD and ammonia nitrogen, nitrite, as well as nitrate after aerobic, reached - 20, 0.9, 0.15 and 21 , respectively. For reference, the initial levels of indicators amounted to 4400, 90, 50, 65, respectively.

During the biological treatment of wastewater, the organic substances are removed by the microorganisms which are immobilized on the surfaces of carriers and are characterized by the oxidative capacity. This indicator was determined using the COD organic fraction concentration in model solutions, measured at the bioreactor inlets and outlets and presented in grams of COD per $1 \mathrm{~m}^{3}$ per day.

The studies on the oxidative capacity of bioreactors depending on the input organic matter concentration of (see Fig. 3) indicate the increase in the oxidation rate along with $\mathrm{COD}$ at the inlets of anaerobic, anoxic as well as aerobic bioreactors.

The bioreactor volume, $W_{i}\left[\mathrm{~m}^{3}\right]$, was determined using the following formula:

$$
W_{i}=\frac{L_{e n}-L_{i}}{O C_{i}} \cdot Q_{\max } \cdot 24
$$

where $L_{e n}, L_{i}\left[\mathrm{mg} / \mathrm{dm}^{3}\right]$ according to COD wastewater bioreactor inlet and outlet, $O C_{i}\left[\mathrm{~g} /\left(\mathrm{m}^{3} \cdot\right.\right.$ day $\left.)\right]$ is oxidation capacity of a bioreactor for COD, established on the basis of experimental data (such as shown in Fig. 3); $Q_{\max }\left[\mathrm{m}^{3} / \mathrm{h}\right]$ is maximum hourly flow of wastewater. 

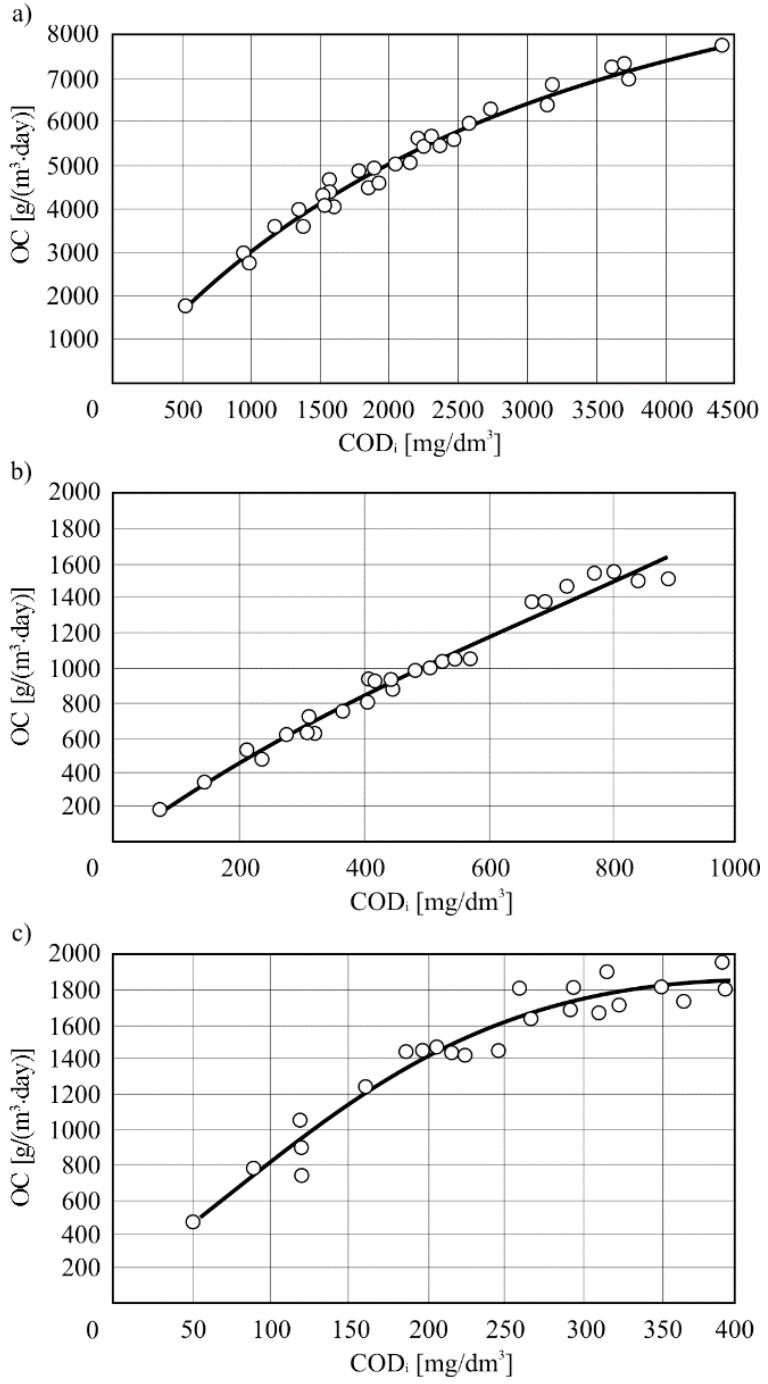

Fig. 3. The relation of the oxidative capacity of bioreactors (OC) to influent wastewater $\mathrm{COD}_{\mathrm{i}}$ : a) anaerobic bioreactor I stage, b) anoxic bioreactor I stage, c) aerobic bioreactor

The anaerobic conditions employed at the first stage and the use of highly fibrous media as carriers of biomass contributed to reaching the highest value of the surface oxidation capacity for COD in the anaerobic bioreactor. Afterwards, it was reduced.

In the case of anaerobic bioreactors, a significant increase in the oxidation capacity occurs along with the growing organic matter concentration in the wastewater as well as COD at the bioreactor inlet. It raised from the value of 2000 to $7700 \mathrm{~g} /\left(\mathrm{m}^{3} \cdot\right.$ day $)$; in turn, COD was increased from the value 520 to $4400 \mathrm{mg} / \mathrm{dm}^{3}$. In the second bioreactor, the oxidation capacity raised - from 400 to $4000 \mathrm{~g} /\left(\mathrm{m}^{3} \cdot\right.$ day), while COD increased from 100 to $2400 \mathrm{mg} / \mathrm{dm}^{3}$. In the case of anoxic bioreactor: the oxidation capacity in the first one 
increased - from 200 to $1600 \mathrm{~g} /\left(\mathrm{m}^{3}\right.$. day) while COD raised from 70 to $900 \mathrm{mg} / \mathrm{dm}^{3}$. In the second one, the oxidation capacity was boosted from 100 to $650 \mathrm{~g} /\left(\mathrm{m}^{3} \cdot\right.$ day $)$, while in COD increased 50 to $550 \mathrm{mg} / \mathrm{dm}^{3}$.

The growing organic matter concentrations at the inlet (from 50 to $400 \mathrm{mg} / \mathrm{dm}^{3}$ ) improved the aerobic bioreactor oxidative capacity - from 100 to $450 \mathrm{~g} /\left(\mathrm{m}^{3} \cdot\right.$ day $)$. In the anaerobic bioreactor, the COD removal efficiency ranged from 70 to $80 \%$. In the second anaerobic bioreactor, the achieved performance changed to the range of 63-74 \%. In the case of the first anoxic bioreactor, the obtained efficiency amounted to 64-71\%, in the second one - 60-69\%, while the lowest performance was achieved in the aerobic bioreactor, amounting to $56-60 \%$.

High values for anaerobic oxidative capacity and anoxic bioreactors prove that biotechnology can be developed, studied and implemented while treating the wastewater with high organic matter concentrations, such as dairy sewage. The COD oxidation capacity of an aerobic bioreactor is low, due to the nitrification process, and therefore it necessitates determining the oxidative capacity for nitrogen compounds.

Overall, the COD treatment effect achieved in the anaerobic, anoxic and aerobic bioreactors amounted to $98-99 \%$, bearing in mind that the initial COD of wastewater exceeded $4000 \mathrm{mg} / \mathrm{dm}^{3}$.

The application of the anaerobic-aerobic method in the bioreactors with carriers for microorganism immobilization during study enabled to achieve high efficiency of organic carbon removal. The microorganism biocenosis was created in separate bioreactor chambers, as a result of their specific design and the single flow of wastewater through them (see Fig. 1). This is typical for the studied conditions and the quality of the sewage in a given chamber. The treatment of wastewater occurs in a gradual manner and the increase of microorganism biomass is reduced owing to the so-called "bioconveyor" [27]. The "predator-prey" relation of microorganisms is formed in a chain of chambers, thus reducing the excess biomass. The higher trophic level of predator decreases the number of its forms [28, 29].

The results of performed biological studies show the presence of large number of microorganisms such as Bodo, Vorticella, Arcella, Oligoheta and others in chamber No. 3. These microorganisms are typical to highly polluted wastewater with large concentration of organic matter as a result of anaerobic destruction of proteins, carbohydrates and others. The small Flagellata are consumed by the Ciliate, Rotifers, Suctoria and others (section No. 5) in the examined wastewater purification process from organic matter and suspended solids, what gives also area for bioindication research [30-38]. These results allow concluding of a small amount of sludge which dewatering well.

The results of the laboratory research show the high degree of milk wastewater treatment. The following degrees of reduction were achieved for the pollutants indicator: COD - 86.7-93 \%, total nitrogen - 96.9-97.9\%. This is a high value compared to the one achieved by recycling technologies $[39,40]$.

The concentration of organic matters and biomass of bacteria decreased in chambers of bioreactors. When the purification process ends, a small amount of the excess biomass remains; therefore, its self-oxidation and self-regulation results from the consumption by higher levels organisms of trophic chains.

During conducting the second part of the research main attention was paid to biogenic substance, namely phosphorous removal. The linear relation involving the phosphate removal efficiency from wastewater using the activated sludge does not implicate that the 
improvement of phosphate removal efficiency has unlimited potential. When the biomass concentration is increased for FAO, the utilized substrate will only be sufficient to maintain life, since it would contribute to increasing the competition between microorganisms and there would be insufficient energy for phosphate accumulation. This statement can be proven by investigating the relation between phosphate removal and the biomass of activated sludge (see Figures 4 and 5). Reduction of the ability of cells for phosphate removal from wastewater (expressed in $\mathrm{mg}$ of phosphate per gram of dry matter biomass) happens at the same time as biomass concentration increase. This effect can be attributed to the fact that each individual cell can remove a greater amount of phosphates when there are fewer competitors on the organic matter, i.e. the substrate.

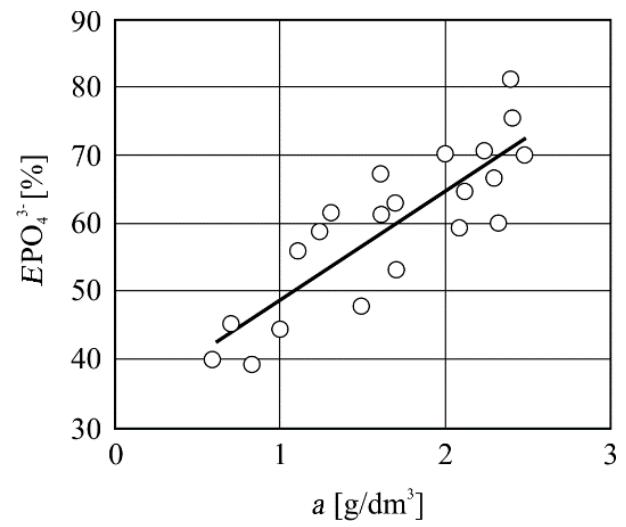

Fig. 4. The relation of the removal efficiency of phosphates concentration $E \mathrm{PO}_{4}{ }^{3-}$ to activated sludge and the dry matter $a$

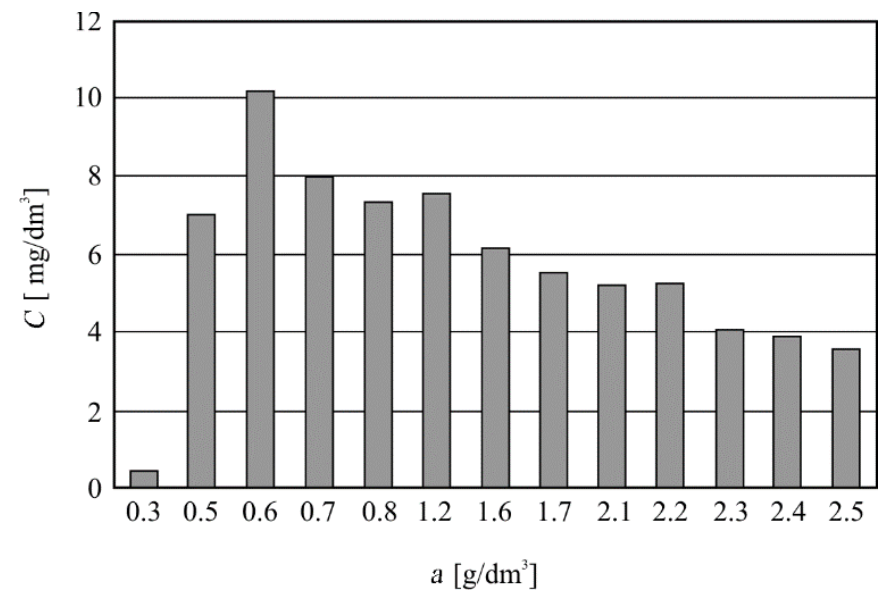

Fig. 5. The relation of the phosphate concentration $C$ removed from the activated sludge concentration

Aeration provides mass transfer and the dissolved oxygen concentration in the bioreactor amounts to 5-7 $\mathrm{mg} \mathrm{O}_{2} / \mathrm{dm}^{3}$. 
The dose of activated sludge equaling $1.7-2.3 \mathrm{~g} / \mathrm{dm}^{3}$ in the system of anaerobic-aerobic bioreactor is almost identical in each of the reactors due to the mixing and continuous return of sludge from the sediment tank to the anaerobic reactor. In the aerobic stage, the removal of excess phosphate concentration and the final removal of organic substances from the wastewater are observed.

In the case of bacterial oxidation, the organic substances are accumulated in the aerobic reactor earlier. The released energy is utilized by cells for absorbing orthophosphates from water, transforming them to polyphosphates and storing in the cells of microorganisms as volutin granules. The mixture comprising water and sludge then flows into the decanter, undergoes separation, and is returned to the anaerobic bioreactor with PAOs. In turn, the excess activated sludge is recirculated to biocoagulators using the pump mounted at the sump bottom. Taking into account the tank diameter, the sump was equipped with a fence in order to prevent the slippage of sludge with wastewater, from the inlet towards the outlet [27].

Research conducted at wastewater treatment facilities during second part of research for the mixture of domestic wastewater and industrial wastewater malting plant (see Fig. 2) confirmed the high degree of purification. It allowed to establish rational values pertaining to the oxidative capacity of bioreactors, COD $\left[\mathrm{g} /\left(\mathrm{m}^{3} \cdot\right.\right.$ day $\left.)\right]$ : I anaerobic - 6200; II anaerobic - 3400, I - II anoxic 800 - 400, respectively; aerobic - 100 (initial COD $1700 \mathrm{mg} / \mathrm{dm}^{3}$ ). The following settings are recommended: specific air flow $\left[\mathrm{m}^{3} / \mathrm{m}^{3}\right]$ for bioreactors: I anoxic - 5 and II anoxic - 3; aerobic - 4.5. Specific active surface of fibrous media in bioreactors is as follows $\left[\mathrm{m}^{2} / \mathrm{m}^{3}\right]$ : anaerobic - 4000, I anoxic - 1500 and II anoxic - 500, aerobic - 400 . This setting is selected depending on the oxidative capacity value, showing that at the end of the purification process, the quantity of excess biomass is small.

\section{Summary and conclusions}

On the basis of conducted studies it is possible to formulate the following conclusions:

- With the purpose of microorganisms biocenosis formation on the principle of "bioconveyor", the application of sectional flow scheme installation for anaerobic and aerobic purification is recommended (patent UA94856, UA97747). The growth of microorganisms biomass reduction resulted from the "predator-prey" relation formed in the sections: from bacteria and small Flagellata to Suctoria, Rotifers, worms and other microorganisms. Establishment of such "bioconveyor" allows reducing the area of new buildings or duration of stay in existing.

- It is possible to arrange fiber carriers of the VIYA type in bioreactors to increase the concentration of microorganisms in anaerobic and aerobic zones. This carrier is characterized by a large surface area and is enables to attach a large quantity of microorganisms.

- The use of attached biomass for the biological treatment of wastewater allows stabilizing the operational conditions in bioreactors. Therefore, changing the quality of input parameters (pollution concentrations) and discharges during prolonged operation time do not affect the performance quality of the treated wastewater at the outlet from wastewater treatment plants with selection and immobilization of microorganism biomass.

- As a result of the presented anaerobic-aerobic industrial wastewater treatment, a small amount of sludge is formed, which dewaters well. 
- Anaerobic-aerobic method of treatment allows to effectively purifying dairy wastewater. The achieved concentrations of pollutants in treated water are: COD $20 \mathrm{~g} / \mathrm{m}^{3}$, and total nitrogen $-2-3 \mathrm{~g} / \mathrm{m}^{3}$.

- The elaborated biotechnology provides efficient treatment that ensures high outflow quality and prevents slipping of the suspended substances, thus meeting the assumed effluent standards. Contaminant concentrations in the treated water after the implementation of biotechnology in the wastewater treatment facilities of malt do not exceed the normative effluent Ukrainian standards [41]: COD - $78 \mathrm{mg} / \mathrm{dm}^{3}$ (limit value - $\left.85 \mathrm{mg} / \mathrm{dm}^{3}\right)$, nitrate nitrogen $-12 \mathrm{mg} / \mathrm{dm}^{3}\left(40 \mathrm{mg} / \mathrm{dm}^{3}\right)$, and phosphates $-2.5 \mathrm{mg} / \mathrm{dm}^{3}$ $\left(3.5 \mathrm{mg} / \mathrm{dm}^{3}\right)$.

- Presented biotechnologies provide high quality of treatment and sustain compliance of sewage effluent parameters with the Ukrainian standards.

\section{References}

[1] Henze M, van Loosdrecht MCM, Ekama GA, Brdjanovic G. Biological Wastewater Treatment. London: IWA Publishing; 2008. ISBN: 9781843391883.

[2] Sabliy L. Physico-chemical and Biological Treatment of Highly Concentrated Wastewater. Rivne: Monograph NUWMNRU. 2013;292. ISBN: 9789663272429.

[3] Bieganowski A, Łagód G, Ryżak M, Montusiewicz A, Chomczyńska M, Sochan A. Measurement of activated sludge particle diameters using laser diffraction method. Ecol Chem Eng S. 2012;19(4):597-608. DOI: $10.2478 / \mathrm{v} 10216-011-0042-7$.

[4] Russell DL. Practical Wastewater Treatment. Second Edition. New Jersey, Hoboken: John Wiley Sons Inc.; 2019. ISBN: 97811195271211119527120.

[5] Jaromin-Gleń K, Babko R, Łagód G, Sobczuk H. Community composition and abundance of protozoa under different concentration of nitrogen compounds at "Hajdow" wastewater treatment plant. Ecol Chem Eng S. 2013;20(1):127-139. DOI: 10.2478/eces-2013-0010.

[6] Ozturk A, Aygun A, Nas B. Application of sequencing batch biofilm reactor (SBBR) in dairy wastewater treatment. Korean J Chem Eng. 2019;36(2):248-254. DOI: 10.1007/s11814-018-0198-2.

[7] Erkan HS, Gunalp G, Engin GO. Application of submerged membrane bioreactor technology for the treatment of high strength dairy wastewater. Braz J Chem Eng. 2018;35(1):91-100. DOI: 10.1590/0104-6632.20180351s20160599.

[8] Drewnowski J, Makinia J, Kopec L, Fernandez-Morales FJ. Modelization of nutrient removal processes at a large WWTP using a modified ASM2d Model. Int J Environ Res Public Health. 2018;15(12):2817. DOI: 10.3390/ijerph15122817.

[9] Lobos-Moysa E, Dudziak M, Zon Z. Biodegradation of rapeseed oil by activated sludge method in the hybrid system. Desalination. 2009;241(1):43-48. DOI: 10.1016/j.desal.2008.02.029.

[10] Waclawek S, Grubel K, Chlad Z, Dudziak M, Cernik M. Impact of peroxydisulphate on disintegration and sedimentation properties of municipal wastewater activated sludge. Chem Pap. 2015;69(11):1473-1480. DOI: 10.1515/chempap-2015-0169.

[11] Babko R, Kuzmina T, Jaromin-Gleń K, Bieganowski A. Bioindication assessment of activated sludge adaptation in a lab-scale experiment. Ecol Chem Eng S. 2014;21(4):605-616. DOI: 10.1515/eces-2014-0043.

[12] Sumathi M, Vasudevan N. Removal of phosphate by Staphylococcus aureus under aerobic and alternating anaerobic-aerobic conditions. Environ Technol. 2018;39(8):1071-1080. DOI: 10.1080/09593330.2017.1320432.

[13] Nasab ARM, Soleymani SM, Nosrati M, Mousavi SM. Performance evaluation of a modified step-feed anaerobic/anoxic/oxic process for organic and nutrient removal. Chin J Chem Eng. 2016;24(3):394-403. DOI: $10.1016 /$ j.cjche.2015.10.010.

[14] Kudlek E, Dudziak M. The assessment of changes in the membrane surface during the filtration of wastewater treatment plant effluent. Desalin Water Treat. 2018;128:298-305. DOI: 10.5004/dwt.2018.22875.

[15] Babko R, Jaromin-Gleń K, Łagód G, Pawłowska M, Pawłowski A. Effect of drilling mud addition on activated sludge and processes in sequencing batch reactors. Desalin Water Treat. 2016;57(3):1490-1498. DOI:10.1080/19443994.2015.1033137.

[16] Vaiopolou E. A modified UCT method for biological nutrient removal: Configuration and performance. Chemosphere. 2008;72(7):1062-1068. DOI:10.1016/j.chemosphere. 2008.04.044. 
[17] Liu JQ, Deng SY, Qiu B, Shang Y, Tian JB, Bashir A, Cheng X. Comparison of pretreatment methods for phosphorus release from waste activated sludge. Chem Eng J. 2019;368(15):754-763. DOI: 10.1016/j.cej.2019.02.205.

[18] Cao JS, Oleyiblo OJ, Xue ZX, Otache YM, Feng Q. Achieving low effluent $\mathrm{NO}_{3}-\mathrm{N}$ and TN concentrations in low influent chemical oxygen demand (COD) to total Kjeldahl nitrogen (TKN) ratio without using external carbon source. Chin J Oceanol Limn. 2015;33(4):1039-1052. DOI: 10.1007/s00343-015-4201-z.

[19] Barnard JL, Dunlap P, Steichen M. Rethinking the mechanisms of biological phosphorus removal. Water Environ Res. 2017;89(11):2043-2054. DOI: 10.2175/106143017X15051465919010.

[20] Fang C, Zhang T, Czechowska-Kosacka A, Pawłowski A, Łagód G, Jiang R, Wang Q. Estimation of phosphorus recovery by struvite crystallization from animal manure wastewater in China. Environ Protect Eng. 2015;41(4):195-207. DOI:10.5277/epe150415.

[21] Jimenez J, Melcer H, Parker D, Bratby J. The effect of degree of recycle on the nitrifier growth rate. Water Environ Res. 2011;83(1):26-35. DOI: 10.2175/106143010X12609736967008.

[22] Guz Ł, Łagód G, Jaromin-Gleń K, Suchorab Z, Sobczuk H, Bieganowski A. Application of gas sensor arrays in assessment of wastewater purification effects. Sensors. 2015;15(1):1-21. DOI: 10.3390/s150100001.

[23] Balbierz P, Knap M. Comparison of methods for solids retention time determination and control. E3S Web Conf. 2017:22:00008. DOI: 10.1051/e3sconf/20172200008.

[24] Drewnowski J, Mąkinia J, Szaja A, Łagód G, Kopeć Ł, Aguilar JA. Comparative study of balancing SRT by using modified ASM2d in control and operation strategy at full-scale WWTP. Water. 2019;11(3):485. DOI: 10.3390/w11030485.

[25] Łagód G, Chomczyńska M, Montusiewicz A, Malicki J, Bieganowski A. Proposal of measurement and visualization methods for dominance structures in the saprobe communities. Ecol Chem Eng S. 2009;16(3):369-377. https://drive.google.com/file/d/16kMQeMGRupbWPc4yhlKh48Uy2wH3g2vG/view.

[26] Gvozdyak P. Based on the principle of bioconveyer (Biotechnology of environment safety). Visnyk of National Academy of Sciences of Ukraine. 2003;3:29-36. http://dspace.nbuv.gov.ua/handle/123456789/70340.

[27] Sabliy L, Kuzminskiy Y, Gvozdyak P, Lagod G. Anaerobic and aerobic treatment of wastewater of milk plants. Proc ECOpole. 2009;3(2):373-378. https://drive.google.com/drive/folders/ 1Jzk3ecjTebTelBcpxKqsVrO6fKq_tOmt.

[28] Sabliy L, Konontsev S. Wastewater treatment biotechnology for the plants of milk industry. Visnyk of UDUVGP. 2003;2(21):142-150.

[29] Del Rozo R, Diez V. Integrated anaerobic-aerobic fixed-film reactor for slaughterhouse wastewater treatment. Water Res. 2005;39(6):1114-1122. DOI: 10.1016/j.watres.2005.01.013.

[30] Fyda J, Babko R, Fialkowska E, Pajdak-Stos A, Kocerba-Soroka W, Sobczyk M, et al. Effect of high levels of the rotifer Lecane inermis on the ciliate community in laboratory-scale sequencing batch bioreactors (SBRs). Eur J Protistol. 2015;51(5):470-479. DOI: 10.1016/j.ejop.2015.09.001.

[31] Foissner W. Protists as bioindicators in activated sludge: Identification, ecology and future needs. Eur J Protistol. 2016;55(Pt A):75-94. DOI: 10.1016/j.ejop.2016.02.004.

[32] Gvozdyak PI, Sapura OV. Simple method of detection and intensivity estimation of anaerobic processes accompanied by gas release. Microbiol Biotechnol. 2009;4(8):53-57. DOI: 10.18524/2307-4663.2009.4(8).103580.

[33] Zhukova V, Sabliy L, Łagód G. Biotechnology of the food industry wastewater treatment from nitrogen compounds. Proc ECOpole. 2011;5(1):133-138. https://drive.google.com/drive/folders/ 1tpAJ9F051yIW0vm3j0S6hbzez4q31QeD.

[34] Bernat K, Kulikowska D, Drzewicki A. Microfauna community during pulp and paper wastewater treatment in a UNOX system. Eur J Protistol. 2017;58:143-151. DOI: 10.1016/j.ejop.2017.02.004.

[35] Parada-Albarracin JA, Perez J, Gomez MA. Bioindicator value of flagellates in urban wastewater treatment using membrane bioreactors. Water Res. 2017;122:526-535. DOI: 10.1016/j.watres.2017.06.033.

[36] Pawęska K, Bawiec A, Pulikowski K. Wastewater treatment in submerged aerated biofilter under condition of high ammonium concentration. Ecol Chem Eng S. 2017;24(3):431-442. DOI: 10.1515/eces-2017-0029.

[37] Amaral AL, Leal CS, Vaz AI, Vieira JC, Quinteiro AC, Costa ML, Castro LM. Use of chemometric analyses to assess biological wastewater treatment plants by protozoa and metazoa monitoring. Environ Monit Assess. 2018;190(9):497. DOI: 10.1007/s10661-018-6882-1.

[38] Machnicka A, Grubel K. Efficiency of biological phosphorus removal by filamentous bacteria. Chem Didact Ecol Metrol. 2016;21(1-2):117-123. DOI: 10.1515/cdem-2016-0010.

[39] Bortoluzzi AC, Faitao JA, Di Luccio M, Dallago RM, Steffens J, Zabot GL, et al. Dairy wastewater treatment using integrated membrane systems. J Environ Chem. Eng. 2017;5(5):4819-4827. DOI: 10.1016/j.jece.2017.09.018. 
[40] Sustersic V, Nesovic A, Gordic D, Donovic K, Terzic I. An overview of wastewater treatment from the milk and dairy industry-case study of Central Serbia. Desalin Water Treat. 2018;133:10-19. DOI: 10.5004/dwt.2018.23006.

[41] Ministerstvo Rehional'noho Rozvytku, Budivnytstva ta Zhytlovo-Komunal'noho Hospodarstva Ukrayiny (Ministry of Regional Development, Construction and Housing and Communal Services of Ukraine). Nakaz (Order) 01.12.2017 No. 316/15.01.2018 No. 56/31508. On Approval of the Rules for the Acceptance of Wastewater to Centralized Wastewater Systems and the Procedure for Determining the Amount of the Fee Charged for Excessive Discharges of Sewage to Centralized Drainage Systems. https://zakon.rada.gov.ua/laws/show/z0056-18/ed20171201?lang=en. 